\title{
PENGEMBANGAN PERANGKAT PEMBELAJARAN DENGAN PENDEKATAN SAINTIFIK MODEL INKUIRI TERBIMBING UNTUK MENINGKATKAN HASIL BELAJAR IPA SISWA KELAS IV SEKOLAH DASAR
}

\author{
Titik Handayani ${ }^{1}$, Soeparman Kardi ${ }^{2}$, Yuni Sri Rahayu ${ }^{3}$ \\ Pendidikan Dasar, Pascasarjana Universitas Negeri Surabaya \\ email: handayani_titik08@yahoo.co.id
}

\begin{abstract}
Abstrak
Penelitian ini bertujuan untuk mengembangkan perangkat pembelajaran dengan menerapkan pendekatan saintifik yang layak digunakan pada materi pokok makhluk hidup dan lingkungannya untuk meningkatkan hasil belajar IPA siswa SD. Subyek penelitian ini adalah siswa kelas IV SD Al Fatah Surabaya sebanyak 12 orang (uji coba1) dan 20 orang (uji coba 2) dengan desain penelitian One Group Pretest-Posttest Design. Hasil penelitian menunjukkan bahwa hasil validasi perangkat pembelajaran oleh validator menunjukkan bahwa perangkat pembelajaran memiliki kualitas baik, valid, dan layak digunakan sebagai perangkat pembelajaran, sedangkan penerapan perangkat pembelajaran pada materi pokok makhluk hidup dan lingkungannya di kelas IV SD adalah praktis dan efektif menunjang kegiatan pembelajaran.
\end{abstract}

Kata Kunci: Pengembangan Perangkat Pembelajaran, Pendekatan Saintifik, Model Inkuiri Terbimbing, Hasil Belajar Siswa

\begin{abstract}
This research has purpose to develop a learning instrument device by applying proper scientific approach which were used in the subject matter of the living beings and the environment to improve the student learning outcomes in elementary school. The subjects of this research were students in the fourth grade of Al Fatah elementary school Surabaya as many as 12 people (trial 1) and 20 people (trial 2) with the design of the research one group pretest-posttest design. The results of the research showed that the results of validation of the learning instrument by a validator showed that the learning instrument have good quality, valid, and fit for being used as a learning instrument, while implementation of the learning instrument in the subject matter of the living beings and the environment in the fourth grade is effective support the learning activities.
\end{abstract}

Keywords: The Instrumen of Development Learning, Scientific Approach, Guided Inquiry Model, Student Results.

\section{PENDAHULUAN}

Kurikulum Tingkat Satuan Pendidikan (KTSP) merupakan kurikulum operasional yang disusun, dikembangkan, dan dilaksanakan oleh setiap satuan pendidikan sesuai dengan potensi sekolah/daerah, karakteristik sekolah/daerah, sosial budaya masyarakat setempat, dan karakteristik peserta didik (BSNP, 2006). KTSP merupakan langkah lanjutan pengembangan Kurikulum Berbasis Kompetensi yang telah dirintis pada tahun 2004 yang mencakup kompetensi sikap (attitude), pengetahuan (knowledge), dan keterampilan (skill) secara terpadu. Hal ini sejalan dengan amanat UU No. 20 Tahun 2003 tentang Sistem Pendidikan Nasional sebagaimana tersurat dalam penjelasan Pasal 35, kompetensi lulusan merupakan kualifikasi kemampuan lulusan yang mencakup sikap, pengetahuan, dan keterampilan sesuai dengan standar nasional yang telah disepakati.
Kurikulum Tingkat Satuan Pendidikan (KTSP) mata pelajaran Ilmu Pengetahuan Alam (IPA) SD/MI berhubungan dengan cara mencari tahu tentang alam secara sistematis, sehingga IPA bukan hanya penguasaan kumpulan pengetahuan yang berupa fakta-fakta, konsep-konsep, atau prinsip-prinsip saja tetapi juga merupakan suatu proses penemuan. Pendidikan IPA diharapkan dapat menjadi wahana bagi peserta didik untuk mempelajari diri sendiri dan alam sekitar, serta prospek pengembangan lebih lanjut dalam menerapkannya di dalam kehidupan sehari-hari. Proses pembelajarannya menekankan pada pemberian pengalaman langsung untuk mengembangkan kompetensi agar menjelajahi dan memahami alam sekitar secara ilmiah (Depdiknas, 2006).

Berdasarkan hasil pengamatan dan wawancara penulis dengan guru di SD Al Fatah Surabaya, hasil belajar siswa pada pembelajaran 
IPA masih belum memenuhi standar ketuntasan minimum. Hasil belajar siswa menunjukkan bahwa 44\% siswa mengikuti ujian ulang karena skor yang diperoleh kurang memenuhi standar ketuntasan minimum yang ditetapkan yaitu 70. Dalam proses pembelajaran terdapat guru tidak menerapkan tujuan pembelajaran secara utuh, misalnya tujuan pembelajaran materi pokok tumbuhan hijau masih terdapat beberapa permasalahan yang ditemukan, diantaranya (1) pembelajaran masih berorientasi pada pemahaman konsep, belum dirancang dan dilaksanakan dengan pendekatan saintifik, akibatnya hasil belajar siswa rendah dikarenakan proses penyampaian konsep belum menghasilkan pemahaman siswa secara utuh; (2) seringkali guru tidak melibatkan siswa dalam aktivitas pengamatan, dan (3) kurangnya keterlibatan siswa dalam mencapai tujuan pembelajaran.

Proses pembelajaran yang dilaksanakan saat ini masih menggunakan paradigma lama yaitu pembelajaran yang berpusat pada guru (teacher centered) dengan memilih pembelajaran langsung dan menggunakan penalaran deduktif. Dalam kegiatan pembelajaran guru lebih mengutamakan memberikan pengetahuan melalui ceramah yang disajikan secara sistematis. Rancangan pembelajaran seperti ini lebih bersifat menghafal. Sadia (2008) mengungkapkan guru masih mempunyai asumsi bahwa pengetahuan dapat dipindahkan secara utuh dari pikiran guru ke pikiran siswa, sehingga guru memfokuskan diri pada upaya penuangan pengetahuan ke dalam kepala siswa. Pembelajaran yang dilaksanakan oleh guru saat ini semestinya sudah mengalami pergeseran menuju ke pembelajaran yang berpusat pada siswa (student center). Pembelajaran dirancang dengan mengoptimalkan potensi yang dimiliki oleh siswa, dengan harapan dapat membantu peserta didik mengkonstruksi pengetahuannya dan menjadikannya pebelajar yang aktif. Paradigma pembelajaran di sekolah saat ini menunjukkan bahwa untuk mengoptimalkan proses pembelajaran diperlukan pelaksanaan pembelajaran yang mengacu pada peningkatan kualitas aspekaspek pembelajaran, seperti penggunaan pendekatan, metode, atau strategi pembelajaran, pengembangan konten atau isi materi ajar, dan pelaksanaan penilaian. Pemilihan dan penggunaan pendekatan, metode, atau strategi pembelajaran yang sesuai dimaksudkan untuk terjadinya pembelajaran IPA yang efektif.
Dalam pelaksanaan pembelajaran, perangkat yang ada saat ini lebih mengedepankan penalaran deduktif. Perangkat pembelajaran hanya berisikan ringkasan materi dan soal, sehingga perangkat pembelajaran saat ini membuat siswa menjadi pasif dan hanya menekankan pada aspek kognitif, sementara aspek keterampilan proses dan keterampilan sosial masih kurang diperhatikan. Hal ini mengakibatkan rendahnya hasil belajar siswa, sehingga guru diharapkan mampu mengembangkan perangkat pembelajaran yang dapat melatih sejumlah keterampilan yang diperlukan siswa untuk mengembangkan kompetensinya. Guru perlu melakukan upaya untuk meningkatkan hasil belajar siswa dengan mengembangkan perangkat pembelajaran agar siswa secara aktif mengkonstruksi sendiri pengetahuan dan keterampilannya guna menemukan fakta-fakta dari suatu fenomena atau kejadian.

Berkaitan dengan hal-hal tersebut di atas, pemerintah melalui Permendikbud No. 65 tahun 2013 tentang Standar Proses Pendidikan Dasar dan Menengah telah mengisyaratkan bahwa siswa memerlukan proses pembelajaran yang dipandu dengan kaidah-kaidah pendekatan saintifik. Pendekatan saintifik merupakan proses pembelajaran yang menggunakan proses berpikir ilmiah (Untari, 2014). Pendekatan atau proses kerja yang memenuhi kriteria ilmiah lebih mengedepankan penalaran induktif daripada penalaran deduktif, karena penalaran induktif memandang fenomena atau situasi spesifik untuk menarik simpulan yang bersifat general (Kemendikbud, 2013). Pembelajaran dengan pendekatan saintifik adalah proses pembelajaran yang dirancang sedemikian rupa agar peserta didik secara aktif mengonstruk konsep, hukum atau prinsip melalui tahapan-tahapan mengamati (untuk mengidentifikasi atau menemukan masalah), merumuskan masalah, mengajukan atau merumuskan hipotesis, mengumpulkan data dengan berbagai teknik, menganalisis data, menarik kesimpulan dan mengomunikasikan konsep, hukum atau prinsip yang ditemukan (Kemendikbud, 2013).

Banyak ahli yang meyakini bahwa melalui pendekatan saintifik, selain dapat menjadikan siswa lebih aktif dalam mengkonstruksi pengetahuan dan keterampilannya, juga dapat mendorong siswa untuk melakukan penyelidikan guna menemukan fakta-fakta dari suatu fenomena atau kejadian. Artinya, dalam proses pembelajaran, siswa dibelajarkan dan dibiasakan untuk menemukan 
kebenaran ilmiah. Mereka dilatih untuk mampu berfikir logis, runut dan sistematis, dengan menggunakan kapasitas berfikir tingkat tinggi (Sudrajat, 2013).

Pembelajaran dengan menggunakan pendekatan saintifik adalah pembelajaran yang menekankan pada pemberian pengalaman secara langsung baik menggunakan observasi, eksperimen maupun cara yang lainnya (Sujarwanta, 2012). Pendekatan pembelajaran saintifik merupakan bagian dari pendekatan pedagogis pada pelaksanaan pembelajaran dalam kelas yang melandasi penerapan metode ilmiah. Metode ilmiah merujuk pada teknik-teknik investigasi atas suatu atau beberapa fenomena atau gejala, memperoleh pengetahuan baru, atau mengoreksi dan memadukan pengetahuan sebelumnya. Untuk dapat disebut ilmiah, metode pencarian (methods of inquiry) harus berbasis pada bukti-bukti dari objek yang dapat diobservasi, empiris, dan terukur dengan prinsip-prinsip penalaran yang spesifik. Karena itu, metode ilmiah umumnya memuat serangkaian aktivitas pengumpulan data melalui observasi atau ekperimen, mengolah informasi atau data, menganalisis, kemudian memformulasi, dan menguji hipotesis (Kemendikbud, 2013).

Salah satu model pembelajaran yang dipandang sejalan dengan prinsip-prinsip pendekatan saintifik adalah inkuiri terbimbing. Model pembelajaran ini berusaha membelajarkan siswa untuk mengenal masalah, merumuskan masalah, mencari solusi/menguji jawaban sementara atas suatu masalah/pertanyaan dengan melakukan penyelidikan (menemukan fakta-fakta melalui penginderaan), pada akhirnya dapat menarik kesimpulan dan menyajikannya secara lisan maupun tulisan (Untari, 2014).

Rangkaian kegiatan dalam proses pembelajaran dengan pendekatan saintifik model inkuiri terbimbing merupakan serangkaian aktivitas yang meliputi: (1) melibatkan siswa dalam aktivitas mental, seperti mengidentifikasi masalah, melakukan pengamatan, merumuskan hipotesis, merancang percobaan, menganalisis data dan menarik kesimpulan; (2) melibatkan siswa dalam aktivitas fisik, seperti melibatkan siswa dalam kegiatan penyelidikan yang dipandu Lembar Kegiatan Siswa; (3) melibatkan siswa dalam aktivitas sosial, seperti menerapkan model pembelajaran yang melibatkan siswa belajar dalam kelompok.
Pembelajaran dengan pendekatan saintifik model inkuiri terbimbing dikembangkan menurut teori konstruktivisme. Dalam teori konstruktivisme dijelaskan bahwa siswa harus dapat menemukan sendiri dan mentransformasikan informasi yang kompleks, mengecek informasi-informasi dengan aturan-aturan lama dan merevisinya apabila aturanaturan tersebut tidak sesuai. Agar siswa benar-benar memahami dan menerapkan pengetahuan, mereka harus bekerja memecahkan masalah, menemukan segala sesuatu untuk dirinya, berusaha untuk menemukan ide-idenya (Slavin, 1994).

Berdasarkan uraian latar belakang di atas, maka perlu dilakukan upaya perencanaan dan pelaksanaan pembelajaran yang diharapkan dapat meningkatkan hasil belajar siswa sekolah dasar. Dengan demikian, maka penulis tertarik untuk melakukan penelitian dengan judul "Pengembangan Perangkat Pembelajaran dengan Pendekatan Saintifik Model Inkuiri Terbimbing untuk Meningkatkan Hasil Belajar IPA Siswa Kelas IV Sekolah Dasar".

\section{METODE}

Penelitian ini merupakan penelitian pengembangan, karena bertujuan mengembangkan perangkat pembelajaran. Perangkat pembelajaran yang dikembangkan adalah Silabus, Rencana Pelaksanaan Pembelajaran (RPP), Buku Ajar Siswa (BAS), Lembar Kegiatan Siswa (LKS), dan Tes Hasil Belajar (THB).

Subjek penelitian adalah siswa SD kelas IV semester satu, tahun ajaran 2015/2016, sebagai sumber data sebanyak 12 orang pada uji coba 1 dan 20 orang pada uji coba 2.

Prosedur dalam penelitian ini terdiri dari tiga tahap. Tahap pertama adalah pengembangan perangkat pembelajaran dengan pendekatan saintifik model inkuiri terbimbing, tahap kedua adalah validasi perangkat pembelajaran, dan tahap ketiga adalah tahap pelaksanaan uji coba perangkat pembelajaran yang dikembangkan. Pengembangan perangkat pembelajaran dalam penelitian ini menggunakan model pengembangan Dick and Carrey.

Model pengembangan Dick and Carrey ini, peneliti mengadaptasi berdasarkan pada ketentuan dan kebutuhan dalam KTSP. Adaptasi yang dilakukan adalah penambahan tahap media pembelajaran yang disejajarkan dengan pengembangan strategi. Kemudian pada tahap validasi perangkat ditambahkan validasi silabus, 
RPP, LKS, buku ajar siswa dan tes hasil belajar yang telah dikembangkan oleh peneliti.

Tahap awal model ini adalah menentukan apa yang diinginkan agar siswa dapat melakukannya ketika mereka telah menyelesaikan program pengajaran. Pada kurikulum, hal itu tertuang dalam standar kompetensi dan kompetensi dasar. Analisis standar kompetensi bertujuan untuk menetapkan arah yang dibutuhkan dalam mengembangkan perangkat pembelajaran. Pada tahap analisis pembelajaran dilakukan dengan menganalisis tujuan dan batasan materi pembelajaran, selanjutnya menentukan model atau pendekatan pembelajaran yang dibutuhkan dan dilakukan oleh siswa untuk mencapai tujuan tersebut. Pada tahap analisis siswa bertujuan u tuk mengetahui karakteristik dari siswa yang diteliti. Perumusan tujuan pembelajaran mempunyai tujuan untuk mengkonversikan hasil analisis tugas dan analisis konsep menjadi tujuan-tujuan pembelajaran yang dinyatakan dengan tingkah laku. Tes beracuan patokan/kriteria merupakan alat evaluasi untuk mengukur ketercapaian indikator yang mengacu pada ketercapaian tingkah laku yang tersurat di dalam tujuan pembelajaran. Strategi pembelajaran merupakan suatu langkah pembelajaran yang dilaksanakan dalam usaha pencapaian tujuan pembelajaran. Oleh karena itu penggunaan strategi pembelajaran disesuaikan dengan indikator hasil belajar.

Setelah perangkat pembelajaran berhasil dikembangkan dan menghasilkan draf 1, selanjutnya diadakan kegiatan validasi perangkat oleh pakar IPA untuk memberikan koreksi dari semua perangkat pembelajaran yang akan diujicobakan dikelas. Koreksi tersebut dapat berupa isi, kebenaran konsep, dan hal-hal esensial yang berpengaruh pada perangkat pembelajaran. Selanjutnya hasil pengembangan perangkat dilakukan ujicoba 1 dan 2. Desain penelitian yang digunakan adalah One Group Pretest-Postest Design. Langkah pertama melakukan pretest sebagai uji awal, selanjutnya dikenakan perlakuan dalam jangka waktu tertentu, kemudian dilakukan uji akhir (postest) (Sugiyono, 2006).

Pengumpulan data dalam penelitian ini menggunakan teknik observasi, tes (pretest dan posttest), dan angket. Observasi dilakukan dengan mengumpulkan data penelitian tentang aktivitas siswa, keterlaksanaan pembelajaran dan hambatanhambatan yang muncul saat kegiatan pembelajaran berlangsung. Tes digunakan untuk memperoleh data tentang hasil belajar siswa. Teknik pengambilan data tes hasil belajar soal pilihan ganda dan uraian. Dilakukan dengan pemberian tes di awal pertemuan KBM (pretest) dan pemberian tes hasil belajar di akhir pertemuan KBM (posttest). Tes dikerjakan secara individual. Sedangkan angket digunakan untuk mengumpulkan informasi data tentang minat dan motivasi siswa terhadap kegiatan pembelajaran dengan pendekatan saintifik model inkuiri terbimbing. Siswa mengisi angket dengan cara menjawab sesuai dengan kriteria yang disediakan.

Analisis data dalam penelitian ini menggunakan statistik deskriptif kuantitatif. Analisis ini digunakan untuk mendeskripsikan karakteristik instrumen pengamatan dan hasil pengamatan yang telah dilakukan terhadap pengelolaan pembelajaran oleh guru, aktivitas siswa, respon siswa, dan ketercapaian atau ketuntasan hasil belajar siswa. Hasil analisis kuantitatif kemudian dideskripsikan secara kualitatif.

\section{HASIL DAN PEMBAHASAN}

Pelaksanaan kegiatan belajar mengajar membutuhkan perangkat pembelajaran yang sesuai dengan karakteristik model pembelajaran dan substansi materi pembelajaran. Tujuan dari penelitian ini adalah untuk mengembangkan perangkat pembelajaran IPA SD yang layak dengan menggunakan pendekatan saintifik model inkuiri terbimbing pada materi pembelajaran hubungan antarmakhluk hidup, rantai makanan dan jaringjaring makanan.

Perangkat pembelajaran yang dikembangkan terlebih dahulu divalidasi oleh validator yang ditinjau dari aspek format, bahasa, dan isi. Berdasarkan hasil validasi, perangkat pembelajaran yang telah dikembangkan dinilai baik dan dapat digunakan untuk penelitian.

Ukuran keberhasilan perangkat pembelajaran yang telah dikembangkan didasarkan pada aspek keterlaksanaan Rencana Pelaksanaan Pembelajaran, respon siswa terhadap pembelajaran, aktivitas siswa selama proses pembelajaran, serta hasil belajar siswa secara klasikal dan individual.

Penerapan perangkat pembelajaran dengan pendekatan saintifik model inkuiri terbimbing ditinjau dari keterlaksanaan RPP, diamati oleh dua orang pengamat. Aspek yang diamati meliputi kegiatan awal, kegiatan inti dan kegiatan akhir. Data yang diperoleh menunjukkan bahwa RPP yang 
dikembangkan mengalami peningkatan dari ratarata $92,86 \%$ dengan skor penilaian 3,52 pada uji coba 1 menjadi 96,43\% dengan skor penilaian 3,65 pada uji coba 2. Hal ini berarti RPP yang dikembangkan dapat diaplikasikan dalam pembelajaran dengan baik sesuai rencana pembelajaran yang dikembangkan.

Suatu pembelajaran dapat terlaksana dengan baik, apabila dalam pelaksanaannya mengikuti langkah-langkah dan skenario pembelajaran yang dirancang dalam RPP dan dilakukan secara runtut dan sistematis. Skenario pembelajaran yang dirancang harus dapat memberikan stimulus yang menantang siswa untuk melakukan kegiatan belajar sesuai RPP yang sudah dikembangkan. Hal ini sesuai dengan yang dikatakan Sanjaya (2011) bahwa selama proses pembelajaran, semua siswa seharusnya ikut terlibat secara langsung agar siswa memperoleh pengalaman dari proses pembelajaran. Salah satu cara untuk membuat siswa ikut terlibat aktif dalam kegiatan pembelajaran adalah melalui pendekatan saintifik model inkuiri terbimbing.

Pengamatan aktivitas siswa selama pembelajaran dilakukan dengan selang waktu tiga menit, dan pengamat mencatat aktivitas paling dominan yang dilakukan siswa selama jangka waktu tiga menit. Adapun rekapitulasi persentase hasil pengamatan aktivitas siswa dalam uji coba 1 dan 2 dapat dilihat dalam Tabel 1.

Tabel 1. Perbandingan Persentase Aktivitas Siswa

\begin{tabular}{|c|c|c|c|}
\hline No & $\begin{array}{l}\text { Aktivitas } \\
\text { yang Diamati }\end{array}$ & $\begin{array}{l}\text { Perser } \\
\text { aktivi } \\
\text { siswa } \\
\text { Uji } \\
\text { Coba } \\
1\end{array}$ & $\begin{array}{l}\text { Uji } \\
\text { Coba } \\
2\end{array}$ \\
\hline 1 & $\begin{array}{l}\text { Mendengarkan atau } \\
\text { memperhatikan } \\
\text { penjelasan guru tentang } \\
\text { materi pelajaran dan } \\
\text { kegiatan yang akan } \\
\text { dilakukan. }\end{array}$ & $\begin{array}{l}12,81 \\
\%\end{array}$ & $\begin{array}{l}13,19 \\
\%\end{array}$ \\
\hline 2 & $\begin{array}{l}\text { Mengemukakan pendapat } \\
\text { atau mengajukan } \\
\text { pertanyaan kepada guru. }\end{array}$ & $\begin{array}{l}12,39 \\
\%\end{array}$ & $\begin{array}{l}12,75 \\
\%\end{array}$ \\
\hline 3 & $\begin{array}{l}\text { Menjawab pertanyaan } \\
\text { yang diberikan oleh guru } \\
\text { secara lisan }\end{array}$ & $\begin{array}{l}10,83 \\
\%\end{array}$ & $\begin{array}{l}11,19 \\
\%\end{array}$ \\
\hline 4 & Membuat hipotesis & $\begin{array}{l}3,65 \\
\%\end{array}$ & $\begin{array}{l}3,91 \\
\%\end{array}$ \\
\hline 5 & Melakukan pengamatan & $\begin{array}{l}14,38 \\
\%\end{array}$ & $\begin{array}{l}14,63 \\
\%\end{array}$ \\
\hline 6 & Mengerjakan LKS & $\begin{array}{l}14,90 \\
\%\end{array}$ & $\begin{array}{l}15,19 \\
\%\end{array}$ \\
\hline
\end{tabular}

\begin{tabular}{clll}
\hline 7 & Melakukan diskusi & 13,85 & 14,31 \\
& $\begin{array}{l}\text { dengan teman dan guru } \\
8\end{array}$ & $\%$ & $\%$ \\
& Mempresentasikan hasil & 11,24 & 10,38 \\
& kerja kelompok & $\%$ & $\%$ \\
9 & Merumuskan kesimpulan & 4,07 & 4,07 \\
& & $\%$ & $\%$ \\
10 & Melakukan aktivitas tidak & 1,88 & 0,38 \\
& relevan & $\%$ & $\%$ \\
& Jumlah & $100 \%$ & $100 \%$ \\
\hline
\end{tabular}

Berdasarkan data Tabel 1 dapat diketahui aktivitas siswa yang dominan pada uji coba 1 dan 2 adalah mengerjakan LKS 14,90\% dan 15,90\%; melakukan pengamatan $14,38 \%$ dan $14,63 \%$, serta melakukan diskusi dengan teman dan guru 13,85\% dan $14,31 \%$. Hal ini disebabkan karena dengan penerapan pendekatan saintifik model inkuiri terbimbing dapat melatih siswa memahami LKS melalui kegiatan pengamatan dengan bimbingan guru. Menurut pendapat Glencoe (2000) dalam Ibrahim (2005) menyatakan bahwa aktivitas pengamatan sangat tepat untuk mengakses kinerja di bidang proses berpikir, pemahaman konsep, penerapan pertanyaan, keterampilan laboratorium, bekerja dengan kelompok kecil, dan pendekatan pemecahan masalah. Selain itu, pada saat melakukan diskusi, semua siswa terlibat aktif dengan anggota kelompok masing-masing dalam mengerjakan LKS, demikian juga pada saat diskusi kelas setiap kelompok mempresentasikan hasil diskusi dengan baik. Sedangkan aktivitas yang jarang dilakukan oleh siswa dalam kegiatan pembelajaran pada uji coba 1 dan 2 adalah merumuskan kesimpulan $4,07 \%$ serta membuat hipotesis $3,65 \%$ dan 3,91\%. Hal ini disebabkan siswa belum terbiasa menyelesaikan LKS dengan pendekatan saintifik model inkuiri terbimbing, sehingga siswa masih kesulitan membuat hipotesis dan merumuskan kesimpulan berdasarkan hasil pengamatan.

Angket respon siswa diberikan kepada siswa setelah pembelajaran selesai dilaksanakan agar peneliti mengetahui respon siswa terhadap pembelajaran. Analisis data hasil angket respon siswa dengan jumlah siswa sebanyak 12 orang pada uji coba 1 dan 20 orang pada uji coba 2 terhadap perangkat pembelajaran, suasana kelas, cara mengajar guru, dan aktivitas pembelajaran dengan pendekatan saintifik model inkuiri terbimbing secara ringkas disajikan dalam Tabel 2. 
Tabel 2. Persentase Respon Siswa Terhadap Pembelajaran Uji coba 1 dan 2

\begin{tabular}{|c|c|c|c|}
\hline $\begin{array}{l}\mathbf{N} \\
\mathbf{0}\end{array}$ & $\begin{array}{l}\text { Uraian } \\
\text { Pernyataan }\end{array}$ & $\begin{array}{l}\text { Persent } \\
\text { Penilaia } \\
\text { Uji } \\
\text { Coba } \\
1\end{array}$ & $\begin{array}{l}\text { e } \\
\text { siswa } \\
\text { Uji } \\
\text { Coba } \\
2\end{array}$ \\
\hline 1 & $\begin{array}{lr}\text { Bagaimana } & \text { perasaanmu } \\
\text { selama } & \text { mengikuti } \\
\text { kegiatan } & \text { pembelajaran } \\
\text { ini? } & \end{array}$ & $\begin{array}{l}\text { senang } \\
100 \%\end{array}$ & $\begin{array}{l}\text { senan } \\
\mathrm{g} \\
100 \%\end{array}$ \\
\hline 2 & $\begin{array}{l}\text { Bagaimanakah pendapat } \\
\text { kamu terhadap } \\
\text { komponen Materi atau isi } \\
\text { pelajaran, Buku Ajar } \\
\text { siswa (BAS), Lembar } \\
\text { Kegiatan Siswa (LKS), } \\
\text { Suasana belajar, Cara } \\
\text { mengajar guru? }\end{array}$ & $\begin{array}{l}\text { tertarik } \\
96,67 \%\end{array}$ & $\begin{array}{l}\text { tertari } \\
\mathrm{k} \\
96,00 \\
\%\end{array}$ \\
\hline 3 & $\begin{array}{l}\text { Apakah kamu merasa } \\
\text { baru terhadap } \\
\text { komponen-komponen } \\
\text { BAS, LKS, Suasana } \\
\text { Belajar dan Cara } \\
\text { mengajar guru? }\end{array}$ & $\begin{array}{l}\text { baru } \\
85,42 \%\end{array}$ & $\begin{array}{l}\text { baru } \\
93,75 \\
\%\end{array}$ \\
\hline 4 & $\begin{array}{l}\text { Apakah kamu dengan } \\
\text { mudah dapat memahami } \\
\text { komponen Bahasa pada } \\
\text { BAS, Materi/isi BAS, } \\
\text { contoh soal, LKS, Cara } \\
\text { mengajar guru? }\end{array}$ & $\begin{array}{l}\text { mudah } \\
83,33 \%\end{array}$ & $\begin{array}{l}\text { muda } \\
\mathrm{h} \\
89 \%\end{array}$ \\
\hline 5 & $\begin{array}{lr}\text { Bagaimanakah } \\
\text { tanggapanmu jika pokok } \\
\text { bahasan } & \text { selanjutnya } \\
\text { diajarkan } & \text { dengan } \\
\text { menggunakan } & \\
\text { pendekatan } & \text { saintifik } \\
\text { model } & \text { inkuiri } \\
\text { terbimbing? } & \end{array}$ & $\begin{array}{l}\text { setuju } \\
100 \%\end{array}$ & $\begin{array}{l}\text { setuju } \\
100 \%\end{array}$ \\
\hline 6 & $\begin{array}{l}\text { Bagaimanakah } \\
\text { penjelasan } \\
\text { bimbingan guru pada } \\
\text { saat mengerjakan LKS } \\
\text { selama kegiatan belajar } \\
\text { mengajar berlangsung? }\end{array}$ & $\begin{array}{l}\text { jelas } \\
100 \%\end{array}$ & $\begin{array}{l}\text { jelas } \\
100 \%\end{array}$ \\
\hline 7 & $\begin{array}{l}\text { Apakah kamu merasa bart } \\
\text { terhadap pembelajarar } \\
\text { dengan menggunakar } \\
\text { pendekatan saintifik mode } \\
\text { inkuiri terbimbing? }\end{array}$ & $\begin{array}{l}\text { baru } \\
90,62 \%\end{array}$ & $\begin{array}{l}\text { baru } \\
92,50 \\
\%\end{array}$ \\
\hline
\end{tabular}

Berdasarkan Tabel 2 menunjukkkan bahwa hasil analisis respon siswa tersebut menunjukkan bahwa sebagian besar siswa memberikan respon positif terhadap pembelajaran dengan pendekatan saintifik model inkuiri terbimbing. Hal ini didasarkan pada pengakuan siswa yang mengatakan sangat jarang dilakukan pembelajaran yang dapat memotivasi siswa untuk terlibat aktif dalam proses pembelajaran. Guru seringkali melakukan metode ceramah sehingga pembelajaran yang dilakukan masih bersifat teoritis. Pelaksanaan pembelajaran dengan pendekatan saintifik model inkuiri terbimbing mampu memberikan pengalaman baru bagi siswa, sehingga siswa terlihat sangat antusias melaksanakan semua kegiatan selama proses pembelajaran. Hal ini sesuai dengan pernyataan Vigotsky dalam Ibrahim (2005) yang menyatakan bahwa perkembangan intelektual terjadi pada saat seseorang berhadapan dengan pengalaman baru dan ketika mereka berusaha memecahkan masalah yang dimunculkan oleh pengalaman tersebut. Respon positif siswa dibutuhkan untuk membangun motivasi siswa. Motivasi merupakan salah satu faktor yang mempengaruhi hasil belajar siswa, sehingga dengan motivasi yang tinggi dapat mencapai ketuntasan individual (Kardi, 2002).

Tes hasil belajar digunakan untuk mengetahui keberhasilan proses pembelajaran yang diukur dari ketuntasan tujuan pembelajaran. Dari hasil analisis pada uji coba 1 dapat diketahui secara keseluruhan siswa dalam pretest tidak tuntas, sedangkan setelah diberi pembelajaran dengan pendekatan saintifik model inkuiri terbimbing semua hasil post test siswa mengalami kenaikan yang signifikan. Rata-rata proporsi butir soal adalah 0,86 , artinya proporsi tujuan pembelajaran (p) $\geq 70 \%$, menunjukkan bahwa semua tujuan pembelajaran sudah mencapai ketuntasan atau ketuntasan tujuan pembelajaran adalah $100 \%$ baik ketuntasan individual maupun klasikal dengan gain skor 0,82 kategori tinggi, sedangkan sensitivitas butir soal berkisar antara 0,33 sampai 0,75 dengan rata-rata 0,55 yang berarti bahwa butir-butir soal yang ada dalam tes hasil belajar menunjukkan tingkat sensitivitas baik.

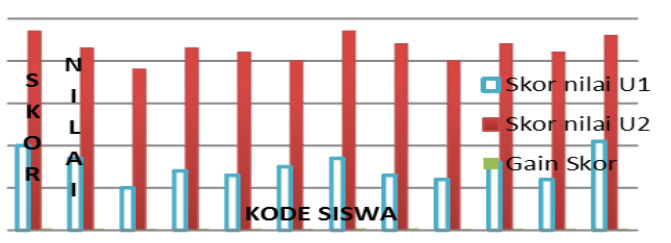

Gambar 1. Perbandingan Skor nilai Pre Test dan Post Test Uji Coba 1

Hal yang sama juga terjadi pada uji coba 2 . Dari hasil analisis pada uji coba 2 dapat diketahui secara keseluruhan siswa dalam pretest tidak tuntas, sedangkan setelah diberi pembelajaran dengan pendekatan saintifik model inkuiri terbimbing semua hasil post test siswa mengalami kenaikan yang signifikan. Rata-rata proporsi butir soal adalah 
0,87, artinya proporsi tujuan pembelajaran (p) $\geq 70 \%$, menunjukkan bahwa semua tujuan pembelajaran sudah mencapai ketuntasan atau ketuntasan tujuan pembelajaran adalah $100 \%$ baik ketuntasan individual maupun klasikal dengan gain skor 0,83 kategori tinggi, sedangkan sensitivitas butir soal berkisar antara 0,55 sampai 0,75 dengan rata-rata 0,67 yang berarti bahwa butir-butir soal yang ada dalam tes hasil belajar menunjukkan tingkat sensitivitas baik. Hal ini menunjukkan bahwa melalui pembelajaran dengan pendekatan saintifik model inkuiri terbimbing yang didukung oleh pemanfaatan perangkat pembelajaran, memungkinkan siswa untuk meningkatkan hasil belajar.

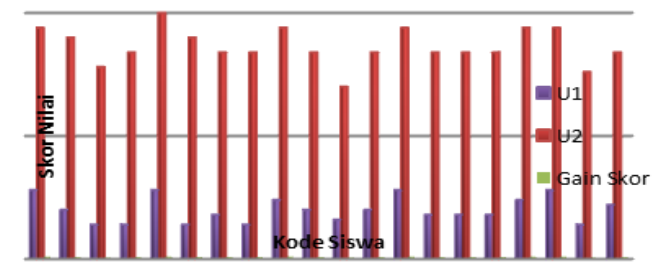

Gambar 2. Perbandingan Skor nilai Pre Test dan Post Test Uji Coba 2

Dalam proses pembelajaran, pengamatan sikap siswa dilakukan oleh pengamat selama kegiatan pembelajaran berlangsung. Pengamatan sikap dilakukan menggunakan lembar pengamatan yang terdiri dari lima kategori yaitu: 1) sikap bekerja sama dalam memecahkan masalah, 2) sikap kejujuran dalam menyajikan hasil pengamatan/data, 3) sikap keterbukaan dan keingintahuan, 4) sikap ketekunan dan ketelitian, 5) sikap bertanggung jawab menyelesaikan tugas. Untuk mempermudah visualisasi terhadap hasil pengamatan sikap pada uji coba 1 dan 2, disajikan pada Gambar 3.

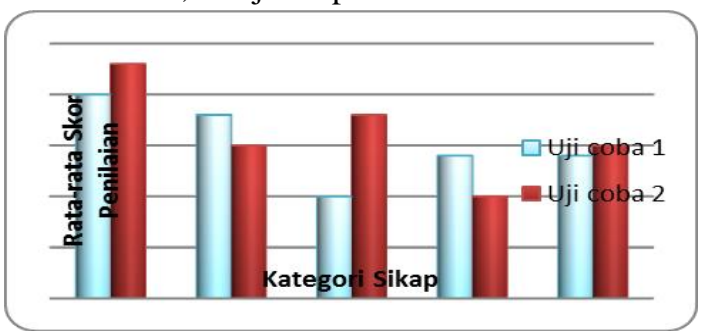

Gambar 3. Perbandingan Hasil Pengamatan Sikap Uji coba 1 dan 2

Berdasarkan Gambar 3 memperlihatkan bahwa pada uji coba 1 dan 2 sikap bekerja sama dalam memecahkan masalah memiliki skor tertinggi. Hal ini dikarenakan dalam mengerjakan LKS siswa menyelesaikan tugas secara berkelompok mulai awal sampai akhir pengamatan, sedangkan pada sikap kejujuran dalam menyajikan hasil pengamatan/data, skor pada uji coba 2 mengalami penurunan dibanding uji coba 1 , hal ini dikarenakan ada siswa pada uji coba 2 yang memanipulasi data sehingga siswa tersebut mencatat data yang tidak sebenarnya. Hal yang sama juga terjadi pada sikap ketekunan dan ketelitian, dimana skor pada uji coba 2 mengalami penurunan dibanding uji coba 1 . Hal ini terjadi karena pada uji coba 2 jumlah siswa dalam satu kelompok lebih banyak dibanding uji coba 1 , sehingga siswa cenderung lebih banyak bermain dengan sesama teman dalam menggunakan lup untuk mengamati gambar dalam LKS.

Gambar 4 juga menunjukkan bahwa pada uji coba 2 sikap keterbukaan dan keingintahuan serta sikap bertanggung jawab menyelesaikan tugas meningkat dibanding uji coba 1. Hal ini dikarenakan pelaksanaan pembelajaran dengan pendekatan saintifik model inkuiri terbimbing mampu memberikan pengalaman baru bagi siswa sehingga siswa terlihat sangat terbuka dan ingin tahu selama kegiatan pembelajaran. Disamping itu siswa juga sangat antusias menyelesaikan tugas yang terdapat di LKS. Secara umum sikap siswa yang ditinjau dari kelima aspek yang diamati menunjukkan kategori baik. Hal tersebut terlihat dari rata-rata skor penilaian dari kelima kategori dalam sikap ilmiah.

Sebagai suatu pembelajaran yang berpusat pada siswa, dengan implementasi pembelajaran menggunakan pendekatan saintifik model inkuiri terbimbing, siswa akan termotivasi dalam belajar karena pembelajaran ini memberikan ruang dan waktu yang luas bagi siswa untuk melakukan pengamatan, menumbuhkan dan mengembangkan sikap dan keterampilan ilmiah untuk memperoleh pengetahuan dan membangun konsep-konsep dibawah bimbingan guru. Guru hendaknya dapat memanfaatkan keingintahuan siswa dan mengembangkan sikap tersebut pada kegiatan penemuan. Inkuiri terbimbing sebagai model pembelajaran yang memberikan kesempatan dan menuntut siswa terlibat secara aktif. Melalui keterlibatan siswa secara aktif dalam suatu pembelajaran, siswa akan memperoleh pengalaman serta dapat mengkonstruksi pengetahuan yang telah terstruktur.

Berdasarkan beberapa hal tersebut diatas, maka dapat disimpulkan bahwa melalui pelaksanaan pembelajaran dengan pendekatan saintifik model inkuiri terbimbing, keterampilan 
siswa dalam bersikap ilmiah dapat tercapai dengan baik.

Dalam proses pembelajaran, pengamatan hasil belajar psikomotor dilakukan oleh pengamat selama kegiatan pembelajaran berlangsung. Berdasarkan hasil analisis pengamatan psikomotor dapat diketahui bahwa pada aspek penilaian cara memegang lup rata-rata skor yang diperoleh pada uji coba 1 dan 2 adalah 3,17 dan 3,21 dengan kategori baik, sedangkan pada cara mengatur jarak antara lup dengan obyek diperoleh rata-rata skor yang diperoleh 3,31 dan 3,30 dengan kategori baik. Kemampuan siswa pada pertemuan 2 cenderung mengalami peningkatan dibanding pertemuan 1 , sehingga dapat disimpulkan bahwa selama kegiatan pengamatan, kemampuan siswa dalam keterampilan mempergunakan lup mengalami peningkatan dan berkategori baik, tetapi masih diperlukan bimbingan agar siswa lebih terampil dalam mempergunakan lup.

Terdapat beberapa hambatan yang dihadapi dalam implementasi perangkat pembelajaran ini, diantaranya yang paling dominan seperti disajikan pada Tabel 3. Meski pada awalnya hambatanhambatan tersebut cukup mengganggu, namun pada akhirnya dapat diatasi dengan langkah-langkah solusi yang dilakukan peneliti.

Tabel 3. Identifikasi Hambatan pada Implementasi Perangkat Pembelajaran

\begin{tabular}{|c|c|c|}
\hline No & $\begin{array}{l}\text { Hambatan- } \\
\text { hambatan }\end{array}$ & Solusi \\
\hline 1 & $\begin{array}{l}\text { Siswa belum terbiasa } \\
\text { bahkan belum pernah } \\
\text { menyelesaikan LKS } \\
\text { dengan pendekatan } \\
\text { saintifik model inkuiri } \\
\text { terbimbing sebagai } \\
\text { contoh riswa } \\
\text { kesulitan menentukan } \\
\text { hipotesis r dan } \\
\text { membuat kesimpulan. }\end{array}$ & $\begin{array}{l}\text { Guru perlu } \\
\text { menjelaskan } \\
\text { tahapan } \\
\text { pembelajaran } \\
\text { dengan pendekatan } \\
\text { saintifik model } \\
\text { inkuiri terbimbing } \\
\text { serta memberi } \\
\text { contoh konkrit } \\
\text { untuk menentukan } \\
\text { hipotesis dan } \\
\text { membuat } \\
\text { kesimpulan. }\end{array}$ \\
\hline 2 & $\begin{array}{l}\text { Waktu pelaksanaan } \\
\text { pembelajaran belum } \\
\text { sesuai dengan } \\
\text { rancangan peneliti. }\end{array}$ & $\begin{array}{l}\text { Guru memperbaiki } \\
\text { pengelolaan waktu. }\end{array}$ \\
\hline 3 & $\begin{array}{l}\text { Alat pengamatan/lup } \\
\text { terkadang dibuat } \\
\text { mainan oleh siswa. }\end{array}$ & $\begin{array}{lr}\text { Guru memberikan } \\
\text { nasihat } \\
\text { bimbingan } \\
\text { siswa dan } \\
\text { bekerja } \\
\text { sungguh-sungguh. }\end{array}$ \\
\hline
\end{tabular}

\begin{tabular}{lrlr}
\hline 4 & Siswa ragu-ragu & Guru & memberikan \\
dalam & menjawab & waktu & untuk \\
pertanyaan $\quad$ dan & menjawab & \\
mengungkapkan & pertanyaan & dan \\
pendapat. Dalam & menunjuk & siswa \\
menjawab pertanyaan & secara acak. & \\
cenderung didominasi & & \\
beberapa siswa saja. & & \\
\hline
\end{tabular}

\section{PENUTUP}

Simpulan

Berdasarkan penyajian data dan hasil penelitian dapat disimpulkan bahwa 1) Pengembangan perangkat pembelajaran berdasarkan pendekatan saintifik model inkuiri terbimbing pada materi pokok makhluk hidup dan lingkungannya, menunjukkan karakteristik valid sehingga layak digunakan dalam pembelajaran, 2) Keterlaksanaan RPP dengan pendekatan saintifik model inkuiri terbimbing dapat terlaksana dengan baik karena semua langkah yang tercantum dalam RPP telah dilaksanakan oleh guru, 3) Aktivitas siswa selama kegiatan pembelajaran menunjukkan bahwa siswa berperan secara aktif, 4) Respon siswa terhadap pembelajaran dengan pendekatan saintifik model inkuiri terbimbing menunjukkan skor ratarata tiap kondisi berkategori baik, sehingga mendukung motivasi siswa untuk terlibat aktif dalam proses pembelajaran, 5) Hasil belajar siswa setelah pembelajaran dengan pendekatan saintifik model inkuiri terbimbing dapat mencapai ketuntasan baik klasikal maupun individual dengan skor peningkatan hasil belajar berkategori tinggi, 6) Hambatan utama yang ditemukan dilapangan adalah siswa belum terbiasa melakukan pembelajaran dengan pendekatan saintifik model inkuiri terbimbing sehingga guru membutuhkan waktu yang cukup lama untuk membimbing siswa melakukan pengamatan dan analisis data sampai merumuskan kesimpulan.

\section{Saran}

1. Berdasarkan simpulan dan hambatan yang ditemukan selama pelaksanaan penelitian, saran yang diberikan peneliti antara lain 1) Persiapan dan pengelolaan waktu perlu diperhatikan dalam menggunakan pembelajaran dengan pendekatan saintifik model inkuiri terbimbing, karena dalam model inkuiri terbimbing siswa membutuhkan waktu yang cukup lama dalam membuat hipotesis, melakukan pengamatan, analisis data dan merumuskan kesimpulan, 2) Perlunya memberi motivasi kepada siswa agar tidak 
merasa kesulitan mengikuti pembelajaran dengan pendekatan saintifik model inkuiri terbimbing, 3) Perlu dilakukan penelitian lanjutan tentang pendekatan saintifik model inkuiri terbimbing.

\section{DAFTAR PUSTAKA}

Depdiknas. (2006). Kurikulum Tingkat Satuan Pendidikan. Jakarta: Depdiknas.

Ibrahim, M. (2005). Asesmen Berkelanjutan: Konsep Dasar, Tahapan Pengembangan dan Contohnya. Surabaya: Unesa University Press.

Kardi, S. (2002). Strategi Motivasi Model ARCS. Surabaya: Universitas Negeri Surabaya

Kementerian Pendidikan dan Kebudayaan. (2013). Lampiran Peraturan Menteri Pendidikan dan Kebudayaan Republik Indonesia Nomor 65 Tahun 2013 tentang Standar Proses Pendidikan Dasar dan Menengah.

Kementerian Pendidikan dan Kebudayaan. (2013). Modul Pelatihan Implementasi Kurikulum 2013. Jakarta: Kementerian Pendidikan dan Kebudayaan.

Sadia, I W. (2008). Model Pembelajaran yang Efektif untuk Meningkatkan Keterampilan Berpikir Kritis. Jurnal pendidikan dan pengajaran Undiksha, 41, 219-237, April 2008.

Sanjaya, W. (2011). Perencanaan dan Desain Sistem Pembelajaran. Jakarta: Kencana Prenada Media Group.

Slavin, R.E. (1994). Educational Psychology. Four Edition. Massachusetts: Allyn and Bacon Publishers.

Sudrajat, A. (2013). Pendekatan Saintifik/ilmiah dalam Proses Pembelajaran. Diunduh dari:

http://akhmadsudrajat.wordpress.com. Pada tanggal 1 Maret 2015.

Sugiyono. (2006). Metode Penelitian Kuantitatif Kualitatif dan $R \& D$. Bandung: Alfabeta.

Sujarwanta, A. (2012). Mengkondisikan Pembelajaran IPA dengan Pendekatan Saintifik. Vol 16 Nomor 1, November 2012.

Undang-Undang Republik Indonesia No. 20 tahun 2003 tentang Sistem Pendidikan Nasional (Sisdiknas). Jakarta: Departemen Pendidikan Nasional.

Uno, H.B. (2008). Perencanaan Pembelajaran. Jakarta: Bumi Aksara.

Untari, M. (2014). Implementasi Pendekatan Saintifik (Scientific Approach) Dalam
Pembelajaran di Sekolah Dasar. Diunduh dari

http://prosiding.upgrismg.ac.id/index.php/pg sd/pgsd/viewfile/321/273. Pada tanggal 9 Maret 2015. 